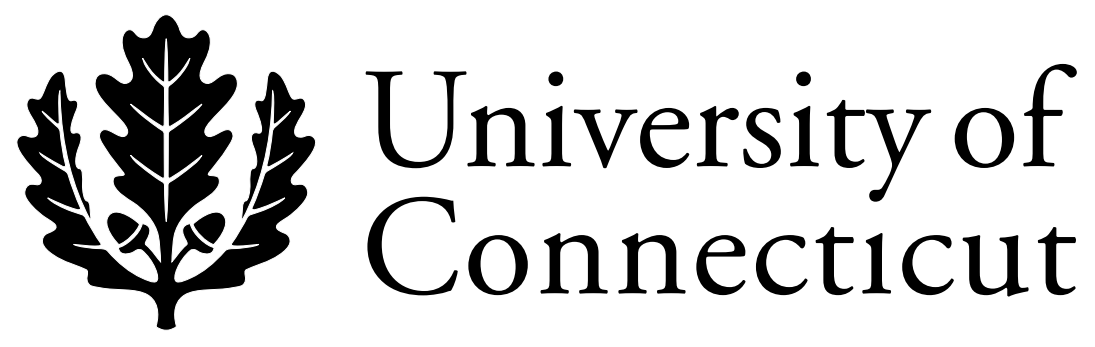

Department of Economics Working Paper Series

Land Inheritance Rules: Theory and Cross-Cultural Analysis

Matthew Baker

United States Naval Academy

Thomas J. Miceli

University of Connecticut

Working Paper 2002-43

July 2000, revised May 2002

341 Mansfield Road, Unit 1063

Storrs, CT 06269-1063

Phone: (860) 486-3022

Fax: (860) 486-4463

http://www.econ.uconn.edu/ 


\begin{abstract}
This paper develops a general theory of land inheritance rules. We distinguish between two classes of rules: those that allow a testator discretion in disposing of his land (like a best-qualified rule), and those that constrain his choice (like primogeniture). The primary benefit of the latter is to prevent rent seeking by heirs, but the cost is that testators cannot make use of information about the relative abilities of his heirs to manage the land. We also account for the impact of scale economies in land use. We conclude by offering some empirical tests of the model using a cross-cultural sample of societies.
\end{abstract}

Journal of Economic Literature Classification: K11, P51 


\section{Land Inheritance Rules: Theory and Cross-Cultural Analysis}

\section{Introduction}

Inheritance of land is of interest to economists because of its importance in determining the ownership and distribution of wealth in society (Pryor, 1973). Yet there is tremendous diversity in the rules and norms that govern the inheritance of real property across different societies and cultures. In some cultures, inheritance is governed by rules that endow the testator with little or no discretion regarding the distribution of his property; examples include primogeniture (inheritance by the eldest son), ultimogeniture (inheritance by the youngest son), and equal distribution among potential heirs. In other cultures, the testator is afforded considerably more discretion, as when the land is passed to the heir judged to be the best qualified to use it. Our objectives in this paper are, first, to develop a general theory of land inheritance that focuses on the incentives land inheritance rules create for potential heirs, and second, to see how well the theory can explain the wide diversity of rules governing inheritance of land across societies. ${ }^{1}$

Of the rules mentioned above, primogeniture is the most widely discussed among both economists and anthropologists, probably because it is relied upon by such a large and diverse collection of societies and cultural groups. A common explanation among economists is that primogeniture prevents land from being fragmented into inefficiently small parcels. ${ }^{2}$ But if increasing returns to scale in land was the impetus for primogeniture, then why not allow testators to allocate the undivided land to the heir best

\footnotetext{
${ }^{1}$ Although we focus on land, much of the analysis is applicable to other forms of property.

${ }^{2}$ For example, Friedman (1985): p. 66) notes that the New England colonies "had little use for primogeniture," while it survived in the South until 1800, "partly because of their system of land use," which tended to involve large estates. In this respect, land tenure in the South more resembled that in
} 
qualified to use it? Such a scheme preserves optimal scale while at the same time expanding the choices of the testator. More generally, why do inheritance customs often restrict the choices of testators with rigid social rules like primogeniture?

The literature on inheritance rules has centered on incentives they create for heirs (and others) to invest in use and maintenance of land. Miller (1980) documents the extensive writing of classical economists on the subject, noting that both Smith and Mill argued that the system of primogeniture in England was flawed because it prevented those who could most ably use land from getting it. Other economists, most notably Malthus and McCulloch, argued that primogeniture in fact created beneficial incentives for potential land users. ${ }^{3}$ More recent discussions have tended to follow the classical literature by emphasizing the incentive effects created by a given rule weighed against the costs of limiting the set of potential land users. ${ }^{4}$

In this paper, we take a somewhat different approach by showing that the primary benefit of a fixed inheritance rule is that it prevents wasteful competition (or rentseeking) among the potential heirs, a problem first discussed in this context by Buchanan (1983). The trade-off is that potential gains are surrendered if a younger heir turns out to be relatively more talented in using the land. The model emphasizes this trade-off between rules and discretion, along with the degree of scale economies in land use, to explain the choice among various land inheritance rules.

\footnotetext{
England than in New England. Also see Posner (1998: pp. 553-554). In contrast, Chu (1991) develops a model that he traces to Adam Smith in which primogeniture serves to preserve family lines.

${ }^{3}$ Though, as Miller points out, Malthus arguments in support of primogeniture rested primarily on the idea that primogeniture created incentives for others to strive to emulate those at the top of the social ladder.

${ }^{4}$ See, for example, Becker (1981) and Bernheim, Shleifer, and Summers (1985). Smetters (1999) provides a good recent review of this literature.
} 
In addition, we examine how a well-functioning land market affects the choice of inheritance rules, an issue that seems to have been ignored in the literature. ${ }^{5}$ We show that a land market renders the inheritance rule largely irrelevant, given that heirs can buy and sell land regardless of how much they receive from the testator. Moreover, since heirs anticipate this, they make efficient prior investments, thereby avoiding wasteful rent seeking. The fact that markets eliminate the benefits of primogeniture suggests that it should not be widely observed in modern (developed) societies, while technologically undeveloped societies (where markets are absent) may not have achieved sufficient economies of scale for its benefits to be realized. The theory therefore implies that the allocative benefit of primogeniture is greatest in societies that have attained an "intermediate" level of economic development.

In testing the theory, we adopt a different approach than previous lines of empirical research on land inheritance, which has typically focused on analyzing the impact of inheritance rules on bequests, or has explored the development and evolution of inheritance rules over time for a specific region. Previous research has also overwhelmingly focused on inheritance rules in Western Society. By contrast, our empirical work is in the tradition of Pryor (1977), and focuses on the incidence of different types of inheritance rules across cultures from all corners of the globe. One advantage of this approach is that it allows the possibility of measuring the relationship between the development of the land market and inheritance rules.

The paper is organized as follows. Section 2 sets up the basic model and describes the testator's objective function. Section 3 considers the case of increasing

\footnotetext{
${ }^{5}$ Though Polanyi (1957, chapter 15) provides some discussion of the ways in which the needs of a modern market economy may undermine traditional institutions governing the distribution of land such as
} 
returns to scale in land use, which implies that a single heir should receive all of the land. Given this result, we compare an unrestricted inheritance rule (best-qualified) to a fixed rule (primogeniture) and show when each is preferred. Section 4 undertakes a similar analysis for the case of decreasing returns to scale. Here, the comparison is between optimal and equal sharing of the land. Section 5 examines the impact of a wellfunctioning land market for optimal inheritance rules. Section 6 explores some empirical implications of the theory using a cross-cultural sample of inheritance rules. Finally, Section 7 concludes.

\section{General Model}

The value of land to heir $j$ is given by the separable production function ${ }^{6}$

$$
x_{j} v(\lambda)
$$

where $x_{j}$ is heir $j$ 's investment in land-specific human capital, and $\lambda$ is the parcel size. The function $v$ is increasing in $\lambda$ (i.e., $v_{\lambda}>0$ ) and $v(0)=0$. The sign of $v_{\lambda \lambda}$ will depend on the nature of the scale economies associated with the land input: if $v_{\lambda \lambda}>0$, there are economies of scale, whereas if $v_{\lambda \lambda}<0$ there are diseconomies of scale. Generally, one expects scale economies for small lots but eventually scale diseconomies as lot sizes increase. ${ }^{7}$ The relevant range here depends on the size of the testator's land holding, which we denote $L$. Below, we consider both the case of scale economies $\left(v_{\lambda \lambda}(L)>0\right)$ and diseconomies $\left(v_{\lambda \lambda}(L)<0\right)$.

primogeniture.

${ }^{6}$ We adopt the separable form for (1) purely for analytical simplicity. None of the qualitative conclusions below rely on it.

${ }^{7}$ This is in fact what Colwell and Munneke (1999) found for urban land markets. 
For simplicity, we assume throughout that there are two heirs. We also assume (for now) that there does not exist a well-functioning land market. Thus, heirs can only acquire land by bequest. This part of the analysis is therefore most relevant for primitive agricultural societies or developing countries in which land is the primary productive resource, and formal institutions like markets are not well developed. (This appears to be an implicit assumption made in much of the literature on inheritance.) Below, we relax this assumption and examine the impact of a land market on optimal inheritance rules.

The model consists of two periods. In the first period the heirs make some investment in land-specific human capital. They make this investment fully cognizant of the rules governing inheritance (or lack thereof) in their society. Then, between the first and second periods, the value of a random variable $\theta$ is realized that reflects the relative abilities of the heirs to manage the land. This ability parameter is distinct from the heirs' investment in $x$, although they can be substitutes for each other. We assume that the support of $\theta$ is the closed unit interval with expected value of $1 / 2$.

In the second period, the testator chooses the shares of his parcel to be given to each heir. Given these shares and the realization of $\theta$, we write the returns to heirs one and two, respectively, as $\theta x_{1} v(s L)$ and $(1-\theta) x_{2} v((1-s) L)$, where $L$ is the size of the parcel to be bequeathed, and $s$ is the share of the land given to heir one. We abstract from the impact of differences in age and suppose that the two heirs are indistinguishable at period one. ${ }^{8}$

The testator's choice of $s$ in period two is made subject to the social rule (if any) governing the distribution of land through inheritance. If there is no rule, the testator can 
choose $s$ in any way he sees fit and cannot credibly commit to a fixed rule beforehand. Since there are no constraints on his choice, we assume that he chooses the shares to maximize the productive potential of his family given all available information (i.e., the $x_{j}$ 's and $\left.\theta\right)$. In contrast, if primogeniture or some other fixed rule is established, the testator is completely constrained in his decision-making. In this case, both heirs know that there is no chance this rule will be changed or violated at the inheritance date.

Once the value of $\theta$ is revealed in period two, the land is awarded to the heirs according to the sharing rule, $s$, subject to the institutional environment. Aggregate welfare from the land upon its transfer is given by the sum of the heirs' returns, or

$$
W=\theta x_{1} v(s L)+(1-\theta) x_{2} v((1-s) L)-c\left(x_{1}\right)-c\left(x_{2}\right)
$$

where $c\left(x_{j}\right)$ denotes the opportunity costs of investing in human capital incurred by each heir, $c>0, c^{M}>0$. (This may be thought of as the cost of not preparing for some alternative career.) Generally, we explore two regimes describing the testator's choice of $s$. Under restricted regimes (primogeniture, equal sharing), $s$ is fixed by social norm before the heirs choose $x_{1}$ and $x_{2}$, whereas under unrestricted regimes (best-qualified, optimal sharing), the testator chooses $s$ at the inheritance date to maximize (2) after observing the realization of $\theta^{9}$ Recall that, absent a norm, there is no way for the testator to credibly commit to a fixed rule beforehand.

We examine both types of rules with the objective of determining when each type is desirable. We begin with the case of scale economies.

\footnotetext{
${ }^{8}$ The heirs could be endowed with a natural difference due, for example, to age, but this complicates the model without adding any additional insights. Thus, we will not distinguish between primogeniture and ultimogeniture.
} 


\section{Scale Economies}

In this section, we consider the case where there are scale economies in land use over the relevant range. That is, $v_{\lambda \lambda}>0$ for lots of size $L$ or smaller. Note that this is the implicit assumption in standard explanations for primogeniture. We first derive the optimal inheritance rule when the testator faces no restrictions.

\subsection{The Best-Qualified Rule}

Under this regime, the testator effectively chooses $s$ on his deathbed to maximize (2) given all available information. We therefore write the optimal value of $s$ selected by the testator as $s^{*}\left(x_{1}, x_{2}, \theta\right)$. The first derivative of (2) with respect to $s$ is given by

$$
\frac{\partial W}{\partial s}=L\left[\theta x_{1} v_{\lambda}(s L)-(1-\theta) x_{2} v_{\lambda}((1-s) L)\right]
$$

and the second derivative is given by

$$
\frac{\partial^{2} W}{\partial s^{2}}=L^{2}\left[\theta x_{1} v_{\lambda \lambda}(s L)+(1-\theta) x_{2} v_{\lambda \lambda}((1-s) L)\right]
$$

The assumption of scale economies implies that the latter expression is positive, or that $W$ is convex in $s$. Thus, the maximum occurs at one of the end-points, $s=0$ or $s=1$. That is, one of the heirs should receive all of the land. The optimal choice of the testator in an unrestricted regime with scale economies is therefore a "best-qualified" rule.

To see how the best qualified heir is determined, note that $s=1$ is optimal if and only if $W$ evaluated at one exceeds $W$ evaluated at zero, or if and only if

$$
\theta x_{1} v(L)>(1-\theta) x_{2} v(L)
$$

\footnotetext{
${ }^{9}$ One might object that maximization of (2) will in some cases disinherit one of the heirs. We could address this problem by adding a constraint that assures a minimum level of income for all heirs. However, this would complicate the model without, we believe, altering our basic results.
} 
After canceling $v(L)$ and rearranging, this condition becomes ${ }^{10}$

$$
\theta>\frac{x_{2}}{x_{1}+x_{2}}
$$

Note that if the two heirs choose the same investment in $x$ (as they will since we have assumed they are identical in all respects as of period one), heir one will get the land if $\theta>1 / 2$, and heir two will get it if $\theta<1 / 2$. Thus, if $\theta$ is symmetrically distributed, then each heir has an equal chance of inheriting the land.

As of period one when the heirs choose their $x$ 's, however, the outcome of condition (6) is probabilistic. If we assume that the heirs act non-cooperatively, then heir one believes he can increase the likelihood that (6) holds (and hence, that he will get all of the land) by raising $x_{1}$, taking $x_{2}$ as given; while heir two believes he can decrease the likelihood that (6) holds by raising $x_{2}$, taking $x_{1}$ as given. As noted above, this creates a classic problem of rent seeking along the lines of that studied by Mortensen (1982). We can therefore prove the following:

Proposition 1: Under a best-qualfied rule, both heirs overinvest in land-specific human capital in the Nash equilibrium. ${ }^{11}$

In the symmetric Nash equilibrium, $\hat{x}_{1}=\hat{x}_{2}=\hat{x}$ (given identical cost of effort functions).

As a result, $\hat{x}_{2} /\left(\hat{x}_{1}+\hat{x}_{2}\right)=1 / 2$, or each heir has an equal probability of being chosen best qualified. If we assume that $\theta$ is distributed uniformly on $[0,1]$, then the expected value of the welfare function under the best-qualified rule is

$$
\hat{W}=\int_{1 / 2}^{1} \theta d F(\theta) \hat{x} v(L)+\int_{0}^{1 / 2}(1-\theta) d F(\theta) \hat{x} v(L)-2 c(\hat{x})
$$

\footnotetext{
${ }^{10}$ Here is where the separability of the production function in (1) matters. In particular, the linearity of the value function in $x$ causes the land component to drop out of this condition, making it depend solely on $x$ and $\theta$.
} 


$$
=(3 / 4) \hat{x} v(L)-2 c(\hat{x}) \text {. }
$$

Note that the coefficient of $3 / 4$ on the first term is greater than $E(\theta)=1 / 2$. This reflects the fact that the land is awarded to the heir with the higher realized value of $\theta$ under the bestqualified rule. ${ }^{12}$ Thus, while the rule induces excessive investment by heirs, it offers this offsetting benefit.

\subsection{Primogeniture}

Primogeniture is a "customary" inheritance rule and hence not subject to change by the testator. Operationally, the rule will no longer be conditional on the realization of $\theta$ or the $x$ 's. Although we focus on primogeniture, our model does not distinguish the heirs by age. Thus, the model applies to any rule that pre-specifies a single heir as the sole inheritor. The reason why primogeniture (or any fixed rule) might be desirable in our model is that it eliminates rent seeking; the drawback is that it may end up awarding the land to the less able heir.

To examine this trade-off, suppose it is pre-determined that heir one will inherit the land. Heir two will clearly choose $x_{2}=0$ in this case, while heir one will solve

$$
\max E(\theta) x_{1} v(L)-c\left(x_{1}\right)
$$

Let $\tilde{x}_{1}$ be the solution to this problem. We then have the following result:

Proposition 2: Under a fixed inheritance rule the designated heir overinvests in $x$ relative to the social optimum.

Heir one overinvests relative to the optimum because he is certain to receive the land under the predetermined rule, whereas under the optimal conditional rule, he would only receive the land if he turned out to be best qualified. (In this sense, heir two underinvests

\footnotetext{
${ }^{11}$ Proofs of all propositions are contained in the Appendix.

${ }^{12}$ In particular, note that for a uniform distribution on $[0,1], 3 / 4=E[\theta \mid \theta>1 / 2]$.
} 
because he has no chance to receive the land under primogeniture, even if he is bestqualified.) Compared to the best-qualified rule, heir one may invest more or less under primogeniture. He will tend to invest more because he is certain to get the land, but he will tend to invest less because there is no rent-seeking effect.

Expected welfare under primogeniture is given by

$$
\begin{aligned}
\widetilde{W} & =E(\theta) \widetilde{x}_{1} v(L)-c\left(\widetilde{x}_{1}\right) \\
& =(1 / 2) \widetilde{x}_{1} v(L)-c\left(\widetilde{x}_{1}\right) .
\end{aligned}
$$

In order to compare primogeniture with the best-qualified rule, we use (7) and (9) to form the difference

$$
\widetilde{W}-\hat{W}=\left[(1 / 2) \widetilde{x}_{1} v(L)-c\left(\widetilde{x}_{1}\right)\right]-[(3 / 4) \hat{x} v(L)-2 c(\hat{x})] .
$$

Re-arranging, we obtain

$$
\widetilde{W}-\hat{W}=\left[(1 / 2) \widetilde{x}_{1} v(L)-c\left(\widetilde{x}_{1}\right)\right]-[(1 / 2) \hat{x} v(L)-c(\hat{x})]+c(\hat{x})-(1 / 4) \hat{x} v(L) .
$$

Note first that the difference between the first two bracketed terms must be positive because, by definition, $\widetilde{x}_{1}$ maximizes the expression in brackets. This, along with the positive term, $c(\hat{x})$, reflect the savings in wasteful rent-seeking expenditures by both heirs under a rule that pre-determines who will get the land. This is the social benefit of primogeniture. The cost, reflected by the last term in (10), is the loss from not being able to award the land to the best-qualified heir. In general, either of these effects might dominate. A fixed rule will therefore be preferred when rent seeking is expected to be severe, while the best-qualified rule will be preferred when ability is expected to be an important factor for efficient land use. 


\section{Scale Diseconomies}

We now turn to the case where there are decreasing returns to scale in the land input for lots of size $L$, or $v_{\lambda \lambda}(L)<0$. In this case, some division of the land between the heirs will be optimal. As above, we consider both restricted and unrestricted inheritance regimes.

\subsection{Optimal Sharing}

We first consider an optimal sharing rule under which the testator determines the shares of each heir after observing $\theta, x_{1}$ and $x_{2}$. The optimal shares, call them $s^{*}$ and $1-s^{*}$, are determined by setting the derivative in (3) equal to zero to obtain

$$
\theta x_{1} v_{\lambda}(s L)=(1-\theta) x_{2} v_{\lambda}((1-s) L)
$$

Given diseconomies of scale, the second-order condition for a maximum is satisfied (i.e., (4) is negative). Comparative statics reveal that $s^{*}$ (heir one's share) is increasing in $\theta$ and $x_{1}$, and decreasing in $x_{2}$. As a result, rent seeking again occurs as heirs compete for a larger share of the land. Thus, we have the following:

Proposition 3: Under an optimal sharing rule, both heirs overinvest in human capital in the Nash equilibrium.

In a symmetric equilibrium, the investment levels are $\hat{x}_{1}=\hat{x}_{2}=\hat{x}$, yielding expected welfare of

$$
\hat{W}=\int_{0}^{1} \theta \hat{x} v\left(s^{*} L\right) d F(\theta)+\int_{0}^{1}(1-\theta) \hat{x} v\left(\left(1-s^{*}\right) L\right) d F(\theta)-2 c(\hat{x}),
$$

where $s^{*}$ satisfies (11) for each realization of $\theta$.

\subsection{Equal Sharing}


The analog to primogeniture in a world of scale diseconomies is a fixed societal rule such as equal sharing $(s=1 / 2)$. In this case, the testator is relieved of discretion, and the heirs realize that the commitment to the rule is credible. Given $E(\theta)=E(1-\theta)=1 / 2$, each heir chooses $x_{j}$ to

$$
\max (1 / 2) x_{j} v(L / 2)-c\left(x_{j}\right), \quad j=1,2
$$

Let $\widetilde{x}_{1}=\widetilde{x}_{2}=\tilde{x}$ denote the optimal investment levels. Note that in this case, there is no rent seeking because the shares are independent of the heirs' choices of $x$.

Expected social welfare under the equal sharing rule is given by

$$
\widetilde{W}=\int_{0}^{1} \theta \tilde{x} v(L / 2) d F(\theta)+\int_{0}^{1}(1-\theta) \widetilde{x} v(L / 2) d F(\theta)-2 c(\tilde{x})
$$

As above, we compare expected welfare under optimal and equal sharing by using (12) and (14) to form the difference

$$
\begin{aligned}
\widetilde{W}-\hat{W}=\int_{0}^{1}[\theta \widetilde{x} v(L / 2)+(1-\theta) \tilde{x} v(L / 2)-2 c(\tilde{x})] d F(\theta) \\
\quad-\int_{0}^{1}\left[\theta \hat{x} v\left(s^{*} L\right)+(1-\theta) \hat{x} v\left(\left(1-s^{*}\right) L\right)-2 c(\hat{x})\right] d F(\theta) .
\end{aligned}
$$

Generally, this expression is ambiguous in sign. On the one hand, it will tend to be positive because $\tilde{x}$ by definition maximizes the first line whereas $\hat{x}$ does not maximize the second line due to rent seeking. On the other hand, $s^{*}$ maximizes the second line for any given value of $\theta$ and $\hat{x}$. Thus, the trade-off is identical to that above: while an optimal sharing rule conditions the shares on the realized abilities of the heirs, it also induces them to engage in wasteful rent seeking. As a result, the preferred rule will depend on which of these effects dominates. 


\section{Impact of a Land Market}

In this section we study the impact of a well-functioning land market on land inheritance rules. Specifically, we assume that land can be bought and sold in any quantity at a fixed price $p$. (To avoid the problem of wealth constraints, we could focus instead on a land rental market or assume a well-functioning credit market.)

Note that existence of a land market adds a possible third period to the above model. Recall that in the first period, heirs make their investments in land-specific human capital $(x)$, and in the second period, the testator allocates his land (if the rule permits) by choosing $s$. In the third period heirs can now buy and sell land. Our principal result in this setting is the following:

Proposition 4: The existence of a perfect land market renders the inheritance rule irrelevant.

Intuitively, if heirs can buy and sell (or rent) land freely, then the final allocation of land will be efficient and independent of the testator's allocation decision. This result, of course, is simply a consequence of the Coase Theorem (Coase, 1960). Further, given the irrelevance of the inheritance rule, we can prove:

Proposition 5: Heirs will choose the efficient level of land-specific investment.

This follows because heirs do not have to compete for their father's land, so rent seeking effects are absent.

The preceding results account for the relative freedom of inheritance in modern societies. They also suggest that inheritance remains an important institution for land transfer in developing countries where the lack of formal property rights inhibits the transfer and collateralization of land. ${ }^{13}$

${ }^{13}$ See, for example, Besley (1995), Alston, et al. (1996), and de Soto (2000). 


\section{Empirical Analysis}

In this section, we employ two complementary data sets to explore the relationships between our theory and patterns in land inheritance in a cross section of societies. Our approach differs from previous literature on land inheritance and primogeniture. One branch of that literature focuses on the impact of inheritance rules on bequests, as in Stiglitz (1969), Pryor (1973), and Menchik (1980); while another consists of detailed historical analysis of inheritance in one region or locale, as in Gagan's (1976) analysis of land inheritance in Ontario, Kennedy's (1991) analysis of farm inheritance in Ireland, or the papers in Goody, Thirsk, and Thompson (1976). Much has also been written about the historical evolution of land inheritance in Western Europe and England (Habakkuk, 1994). In contrast, our research studies the incidence of inheritance rules using a representative sample of world cultures. We employ the methodology pioneered by Pryor (1977), and used more recently by Anderson and Swimmer (1997) in their analysis of land ownership, and Stodder (1995) in his analysis of institutions governing exchange. In a similar fashion, we use our theory as a tool to explore broad trends in inheritance rules across a sample of societies that vary widely in technological and institutional sophistication.

Generally, we find that there is positive correlation between the occurrence of fixed inheritance rules and the level of technological, social, and political development. However, we also find evidence that more technologically advanced societies are more likely to have land markets, which in turn lessens the chances that a fixed inheritance rule will be employed. Among those societies in which inheritance rules are present, we find evidence supporting the conjecture that scale economies lead societies to rely upon sole 
heir inheritance rules (such as primogeniture), as opposed to dividing land among heirs. Finally, we find limited support that the incidence of fixed sole heir rules is correlated with social prestige and with transactions costs.

\subsection{Description of the Data and Empirical Specification}

Our data derives primarily from the Standard Cross Cultural Sample (SCCS), started in Murdock and White (1969). ${ }^{14}$ The SCCS contains information on the material culture, technology, and institutions of 186 different societies from all corners of the world. Almost every cultural group in the world is represented in the sample. The SCCS includes a rich variety of societies covering a wide range of development levels, including hunter-gatherers (such as the Mbuti Pygmies), and complex nation-state cultures (such as the Romans).

Our primary dependent variable, the presence of a fixed rule governing inheritance, derives from the information provided by the SCCS on "The rule or practice governing the disposition or transmission of a man's property in land." For each society, Murdock reports the nature of the land inheritance rule based on whether inheritance is best described by 1) equal or relatively equal distribution between heirs, 2) primogeniture, 3) exclusive inheritance by the best-qualified heir, 4) ultimogeniture, or 5) absence of a fixed rule or "no knowledge" of the rule. Our empirical work will focus on comparison of those societies employing fixed rules with those that do not. We also study the frequency of primogeniture among those societies that employ fixed inheritance rules.

\footnotetext{
${ }^{14}$ The SCCS originally appeared in a series of papers in Ethnology in the late 1960's and early 1970's, which collectively describe the data in detail. For these sources, see Murdock and Provost (1973). The data in the SCCS is based on Murdock's (1967) Ethnographic Atlas, which contains a much larger sample of societies, but is less complete. This data, and related data sets, are generally available in digital form. See White (1992) for the Ethnographic Atlas and Stark (1987) for a description of the SCCS. The SCCS can also be acquired on the world wide web; see http://eclectic.ss.uci.edu/ drwhite/worldcul/index.html. To our knowledge, Pryor's (1977) does not exist in digital form.
} 
For purposes of the analysis, we classify societies using equal or relatively equal distribution, primogeniture, and ultimogeniture as having fixed inheritance rules; and those using a best-qualified rule or no reported rule as having no fixed rules.

This methodology has two drawbacks. First, those societies for which information is missing may actually have rules, or may not practice land ownership at all. Second, the category "equal or relatively equal" may in fact allow some degree of discretion in land allocation among heirs. These difficulties, however, stack the deck against finding meaningful statistical relationships when none actually exist, and thus decrease the chances that we might reach false conclusions in interpreting results.

Since the presence of scale economies in land use, and the degree to which heirs must learn land-specific tasks, are important factors in our theory, we must first capture quantitatively the likelihood that some sort of scale economies are present, and more generally, the importance of technology and skill in using land. Almost any technological development increases the likelihood of scale economies, including better land cultivation techniques, the quality of tools available to workers, the degree to which workers are specialized, or the means by which goods are transported. Less obvious things may also contribute to scale economies in land use, such as a society's capacity to store information and keep records, or a society's capacity to enforce and maintain rules. Demographics, such as the density and spatial distribution of population, and characteristics of social organization, such as the degree to which political institutions are present and developed, may also lead to scale economies in land use.

While these ideas are difficult to capture quantitatively in any setting, the SCCS provides several useful "scale" variables, which are designed to measure the complexity 
of each society across ten different dimensions. The SCCS's ten scale variables measure the development of writing and record-keeping systems, fixity of residence, nature and importance of agricultural technology, degree of urbanization, extent of craft specialization, nature of land transport, the nature and presence of currency, population density, and the degree to which the society has a politically integrated hierarchy. Also reported by the SCCS is "the degree of social stratification," which measures the extent to which a society is stratified into social classes. We shall have occasion to treat this variable separately from the other scales, as it may pertain directly to theories of land inheritance based on social standing. For example, Chu argues that primogeniture may result from a lineage's welfare maximizing response to a social system linking status and wealth. Thus, we might expect social stratification to be positively correlated with primogeniture, apart from any impact it may have on social development or technology.

All the scale variables run from a minimum of one to a maximum of five, and the exact meaning of each is described in detail in Table 1. Murdock and Provost contains a thorough description of the details and difficulties encountered in the construction of these measures. A final useful device, also engineered by Murdock and Provost, is an aggregated version of the scale variables, which Murdock refers to as a "composite index of cultural complexity." This aggregate index is the sum of all the scale variables. ${ }^{15} \mathrm{We}$ shall also employ this composite index at places in our analysis as a convenient catch-all measure for the level of development and technology in a society.

The presence or absence of a land market is a central element of our theory, which we argue should reduce the likelihood that a society relies on a fixed inheritance rule of any sort. That said, information on whether or not a society possesses a well-functioning 
land market is exceedingly difficult, if not impossible, to obtain for the majority of societies in the SCCS. Pryor's (1977) The Origins of the Economy, however, contains information on the presence and importance of land markets for a smaller sample of societies, a large fraction of which also appear in the SCCS. For each of the 60 societies in his dataset, Pryor reports varying degrees of land market presence and importance, noting whether 1) land sales do not occur, 2) land sales do occur but do not seem important, 3) land sales occur and do seem important, 4) land is only bought and sold with nonmembers of the society. Pryor further notes whether 1) land rental does not occur, 2) land rental occurs but is unimportant, 3) land rental occurs and is important, and 4) land rental occurs only with nonmembers of society. We formulate a dummy that awards each society a one if land sales or land rental occurs within that society and "is important," and zero otherwise. Land markets are unlikely to be well functioning if they are unimportant (recall our theory relies upon the land market being competitive), and if land purchase or rental transactions are conducted only with outsiders (perhaps because the land market is the result of colonialism or even extortion). Of the 60 societies that appear in Pryor's data set, 42 societies also appear in the SCCS, and according to our definition, 7 of the 42 had a well-functioning land market. We make use of these data to develop a predictive model of the probability that a society has a well-functioning land market using the 42 societies for which information is available. We then employ the result to generate a probabilistic prediction that any society has a well-functioning land market. Before performing this operation, it is useful to have a closer look at the data and note some of the points of interest and difficulties involved in performing this task.

\footnotetext{
${ }^{15}$ We thank an anonymous referee for recommending the use of this variable.
} 
Table 2 presents bivariate correlations between each of the scale variables, and the Spearman correlation coefficient between the scale variables. The last row of Table 2 shows the Spearman correlation coefficient between each scale variable and the land market dummy for the 42 societies appearing both in Pryor's data set and in the SCCS. The last column of Table 2 shows the correlations between each of the scale variables and the composite index. It is immediately apparent that the scale variables are almost without exception positively and significantly correlated with one another, and with the existence of a land market. This is not surprising as technological development in one dimension may precipitate development in another, or the development and adoption of different types of technology may be complementary. To the extent that almost any innovation allows specialization, which generates possibilities for exchange, it is also not surprising that each scale variable, and in particular the technological specialization scale variable, is strongly correlated with the existence of a market. On some level any of the scale variables could be the cause, or the result, of market development. For example, population density, fixity of residence, and urbanization could all increase as a result of the development of a land market, but by the same token, each may also precipitate development of a market if only by making land a more scarce commodity.

From Table 2, the composite complexity index is strongly and somewhat uniformly correlated with each scale variable and also with the presence of a land market. A simple inference one might derive from this rough comparison is that technological, political, and social development are generally complementary, in that societies do not systematically develop along one technological dimension at the expense of others. Given 
these points, it is difficult to choose one scale variable as "the" indicator that best predicts the existence of a land market.

Since we wish to develop a proxy of the likelihood of land markets across our entire dataset, it is necessary to find a suitable instrument for the emergence of a land market. We have elected to rely on the composite complexity index as our sole predictor of the likelihood a well-functioning land market exists. We thus fit the following the logit model:

$$
\begin{aligned}
\operatorname{Ln}\left[P_{l m k} t /\left(1-P_{l m k t}\right)\right]= & -11.097+.284 \text { Comp. Complexity Index } \\
& (3.699)(.100) \\
N= & 42, \text { Psuedo- } R^{2}=.635^{16}
\end{aligned}
$$

where $P_{l m k t}=1$ if the society has a land market, and 0 otherwise. This model was then applied to the each of the 186 societies to generate a predicted probability that each society has a well-functioning land market.

We rely on this simple model for two primary reasons. First, for such a small number of available observations, maintaining degrees of freedom is an obvious concern. Use of the total development index allows us to preserve degrees of freedom while simultaneously allowing a wide variety of different technological factors to influence the presence or absence of a land market. ${ }^{17}$ Second, the resulting predictions generated by the logit model are not linear combinations of any of scale variables. Thus, when we estimate models for the presence or absence of fixed inheritance rules, there is no need to exclude scale variables to identify the model. Indeed, we have no reason a priori to favor

\footnotetext{
${ }^{16}$ The Pseudo- $\mathrm{R}^{2}$ that we present here and in other parts of the paper is the one developed by Nagelkerke (1991), and is defined as $R=\left(1-L_{0} / L_{b}\right)^{2 / n} /\left(1-L_{0}\right)^{2 / n}$, where $L_{0}$ denotes the value of the likelihood function for the restricted model, and $L_{b}$ denotes the likelihood function for the unrestricted model. It is a correction of the more widely known Cox and Snell Pseudo- $\mathrm{R}^{2}$.

${ }^{17}$ In fact, Pryor (1977) uses almost exactly the same model in his study of the emergence of land markets.
} 
one technological scale variable over another in its capacity to predict scale economies, and allowing each to enter into our econometric models allows us to see along which dimensions technology and complexity vary with land inheritance rules. While we run the risk of introducing multicollinearity among independent variables, this does not bias coefficient estimates but merely reduces the possibility that we will find relationships when they do not exist.

\subsection{Results}

Tables 3 and 4 present means of the data broken down, respectively, according to region and inheritance rules. Table 3 breaks the data down according to six main geographical regions into which both Murdock and Pryor divided their samples. It is evident that Circum-Mediterranean societies are, by just about any standard, the most complex and technologically advanced in the SCCS, and also have a significantly higher predicted probability of land market existence. Eurasian societies also appear to be systematically more complex than the others in the sample, while the African and Insular Pacific societies lie towards the middle of the development spectrum. South American and North American societies appear to be systematically less technologically and socially complex than others. Table 3 also reveals that fixed inheritance rules appear to occur with greater frequency among societies in regions that are on average more complex such as the Circum-Mediterranean, and occur much less frequently among the systematically less complex cultures of North America and South America. The inference one might draw from this simple look at the data is that land markets, technological and social sophistication, and inheritance rules are all positively correlated. 
Table 4 breaks down scale variables and the predicted probability of a land market by nature of inheritance rule. From this data, one arrives at the same conclusions reached from the regional breakdown of the data: technology and complexity, a land market, and the presence of land inheritance rules all appear to be positively correlated. However, no clear distinctions emerge between those societies that have rules and those that do not.

The first two columns of Table 5, labeled I and Ia, present logistic models which take the presence (dependent variable $=1$ ) or absence of a fixed land inheritance rule as the dependent variable, where each of the scale variables and the predicted probability of a land market enter as independent variables. These models reveal sharply different features of the data than our preliminary comparisons of means and correlation coefficients. Both models I and Ia suggest that, controlling for technology and complexity, the predicted probability of a land market has a significantly negative impact on the likelihood that a fixed inheritance rule is observed. Thus, our hypothesis that land inheritance rules are negatively impacted by the existence of markets appears to be confirmed, after controlling for the impact of technology. Moreover, the estimated models broadly bear out our contention that more developed technology favors fixed inheritance rules. Of the technological and social scale variables, the one with the most significant economic impact is the scale measuring technological specialization.

Other significant variables include the development of writing and records, the sophistication of land transport, and the fixity of residence. Of these variables, the one with the least obvious interpretation, in that it doesn't appear to bear directly on the complexity of land-use technology, is the sophistication of writing and records. However, 
a more developed writing system may lead to more well-defined land rights, and also allow easier transfer of land, each of which might magnify the importance of learning to use land and/or the incentives to invest time in learning to use land.

There are two exceptions to this trend: both the agricultural scale variable and the urbanization scale variable have significant and negative signs. An explanation for this might be as follows. If agriculture is the most important source of livelihood for the largest variety of people in the sample, it may well be the case that opportunities are not available for other heirs. ${ }^{18}$ Also, in a more urbanized society, land and land ownership may be less important than other types of property, reducing the need for fixed inheritance rules.

The social stratification variable turned out to be insignificant. This is not surprising as we might expect this variable to explain the incidence of primogeniture rather than the existence of a rule in general. We discuss this variable further in the context of models that explain the use of sole heir rules among those societies that employ some rule.

The next two models, II and IIa, fit two simple logit models that examine the incidence of primogeniture among only those societies that have fixed inheritance rules. These two models did not perform as well as our previous two, but do yield some interesting insight into the nature of primogeniture. In model IIa, we removed the social stratification variable and replaced it with a dummy variable called "dual stratification," which, according to Murdock, is the state of affairs when a society is stratified "...into a

\footnotetext{
${ }^{18}$ Interestingly, Murdock notes that descent patterns follow a similar pattern. Bilateral descent predominates at low and high levels of development, but is replaced by more specialized rules at middle levels of development. While Murdock makes note of this phenomenon, he does not attempt to explain it,
} 
hereditary aristocracy and a lower class of ordinary commoners or freemen, where traditionally ascribed noble status is at least as decisive as control over scarce resources" (Murdock, 1967: 58). We included a dummy if dual stratification existed and zero otherwise, as we felt it was most relevant to arguments like Chu's: namely, that primogeniture is a natural way that status can be upgraded or maintained. The significantly positive coefficient on the variable suggests that this is indeed the case.

Model IIa attempts to increase the performance of the model by excluding insignificant independent variables to reduce multicollinearity and by including the new dual stratification dummy variable. The technological specialization index and the complexity of the writing and record keeping are now significant at the $1 \%$ and $5 \%$ levels, respectively. The strong positive sign of technological specialization is in line with the predictions of the model, but it may also pick up an effect that measures the possibilities available to heirs who do not receive the land. One interpretation of this is that the opportunity costs of learning how to use land are relatively high, and thus should be avoided by having a fixed-sole-heir rule.

The negative sign of the writing and records coefficient could indicate a transaction cost reason for using primogeniture. If the writing/record keeping system is poor, keeping exact records of land divisions may be prohibitively costly. Thus, a fixed sole heir rule such as primogeniture may ease the transactions costs associated with defining and maintaining land rights.

To get an idea of the importance of some of the salient features in the model explaining the incidence of fixed sole heir rules, we fit two simple models that rely 
wholly on the composite complexity index. The first model restates the model we used to predict the probability of a land market, while the second replaces all technological variables in Model I above with the composite complexity index.

$$
\begin{aligned}
& \operatorname{Ln}\left[P_{l m k t}\left(1-P_{l m k t}\right)\right] ?=-11.097+.284 \text { Comp. Complexity Index } \\
& \text { (3.699) (.100) } \\
& N=42, \text { Psuedo }-R^{2}=.635 \\
& \operatorname{Ln}\left[P_{f r} /\left(1-P_{f r}\right)\right]=-2.469+.127 \text { Comp. Complexity Index }-2.313 \text { Land Market Prob. } \\
& \text { (.754) (.033) (1.178) } \\
& N=186, \text { Psuedo }-R^{2}=.164
\end{aligned}
$$

In the second equation, $P_{f r}$ equals 1 if a society has a fixed rule and zero otherwise. These two equations describe, respectively, the predicted impact of technological and social development on the likelihood of a land market, and both the direct and indirect impact (through the increase in likelihood of a well-functioning land market) of technological and social development on the incidence of fixed inheritance rules. Since both dependent variables ultimately depend on one argument, predicted probabilities can be easily plotted on a diagram, which is done in Figure 1. The figure plots the predicted values of the probability of a land market, the predicted probability of a fixed inheritance rule setting the land market probability to zero, and the predicted probability of a fixed inheritance rule when the predicted probability of a land market is allowed to vary accordingly.

In interpreting the graph, note first that the chances of a land market existing appear to increase rapidly after a complexity threshold is reached. Further, the reduction in the likelihood of observing a fixed rule appears to lie in approximately the $10 \%$ range at the upper part of the complexity spectrum. While this is far from verifying that a rule is 
rendered irrelevant by the existence of a land market, it does admit the general idea that markets may replace institutions regulating behavior. Perhaps this notion would be borne out to a greater degree in a sample that included better information on the existence and operation of a land market, or a sample that also included information for more modern societies.

Interestingly, these ideas provide a potential explanation for a puzzle mentioned by Murdock and Provost (1973: 391-392) within the context of discussion of descent rules and their relationship to cultural and technological complexity. They noted that bilateral, flexible descent rules proliferate among societies at the tail ends of the complexity distribution, while more specialized and rigid descent systems appear among societies at the middle of he complexity distribution. Murdock and Provost leave the phenomenon unexplained, writing "This essentially bimodal or curvilinear distribution is inconsistent with any unilinear interpretation of social development." (Murdock and Provost, 1973: 392). Our results suggest that societies at the low end of the technological spectrum have no need for fixed social rules, since issues of suboptimal investment in learning, and the general importance of skill and technological sophistication, have not yet asserted themselves in economic life. In contrast, societies at the high end of the spectrum are more likely to have well functioning markets, which render rules moot.

\section{Conclusion}

In this paper we have developed a model in which heirs make human capital investments in learning to use their father's land prior to inheritance. In this framework, the primary benefit for passing all land to a single heir is returns to scale. Adopting a rule that designates a fixed sole heir has the further benefit of forestalling excessive 
competition between heirs in investing to use the land, but the drawback is that it does not allow potentially beneficial adjustment of the inheritance bundle. Thus, in an imperfect world, neither a fixed-sole-heir rule nor a best-qualified rule achieves the first best outcome. We find, however, that in a world in which land markets function well, the inheritance rule is irrelevant. The testator is indifferent between potential allocations among his heirs when armed with the knowledge that they may buy and sell land.

Broad empirical regularities support aspects of our theory. For example, we find that cultures employing fixed sole heir rules, such as primogeniture or ultimogeniture, tend to exhibit scale economies in land, but at the same time have not sufficiently developed agricultural technology allowing for a land market. Thus, they are in some sense "intermediate" in their level of development. We also find limited evidence that fixed sole heir rules are more likely when a greater variety of alternative occupations are open to potential heirs. Finally, preservation of social status, whether or not there is a land market, appears to be a major impetus for adoption of fixed-sole-heir rules.

\section{Acknowledgements}

We thank two anonymous reviewers and the editor for their very helpful comments. 


\section{Appendix}

Proof of Proposition 1: Let $F(\theta)$ be the distribution function for $\theta$. Thus, (6) implies that $1-F\left(\frac{x_{2}}{x_{1}+x_{2}}\right)$ is the probability that $\mathrm{s}=1$, and $F\left(\frac{x_{2}}{x_{1}+x_{2}}\right)$ is the probability that $s=0$. The problem for heir one is therefore to

$$
\max \left[1-F\left(\frac{x_{2}}{x_{1}+x_{2}}\right)\right] E\left(\theta \mid \theta>\frac{x_{2}}{x_{1}+x_{2}}\right) x_{1} v(L)-c\left(x_{1}\right)
$$

Given that

$$
E\left(\theta \mid \theta>\frac{x_{2}}{x_{1}+x_{2}}\right) \equiv \int_{x_{2} /\left(x_{1}+x_{2}\right)}^{1} \theta d F(\theta) /\left[1-F\left(\frac{x_{2}}{x_{1}+x_{2}}\right)\right]
$$

(A1) becomes

$$
\max \int_{x_{2} /\left(x_{1}+x_{2}\right)}^{1} \theta d F(\theta) x_{1} v(L)-c\left(x_{1}\right)
$$

Equating marginal benefits and marginal costs implies

$$
\int_{x_{2} /\left(x_{1}+x_{2}\right)}^{1} \theta d F(\theta) v(L)+\left(\frac{x_{2}}{x_{1}+x_{2}}\right) f\left(\frac{x_{2}}{x_{1}+x_{2}}\right) x_{1} v(L)\left[\frac{x_{2}}{\left(x_{1}+x_{2}\right)^{2}}\right]=c^{\prime}\left(x_{1}\right),
$$

which defines heir one's reaction function. This, along with the corresponding reaction function for heir two, determines the equilibrium investment levels $\left(\hat{x}_{1}, \hat{x}_{2}\right)$. Note that the second term on the left-hand side of (A3) reflects the increase in the probability of inheritance resulting from an increase in $x_{1}$. It therefore captures the rent-seeking effect.

The socially optimal investment levels, defined to be the levels that the testator would "instruct" the heirs to choose (if he could), maximize the joint expected value in (2). Equating the marginal social benefit and marginal social cost for heir one yields 


$$
\int_{x_{2} /\left(x_{1}+x_{2}\right)}^{1} \theta d F(\theta) v(L)=c^{\prime}\left(x_{1}\right)
$$

which, along with the corresponding condition for heir two, determines the optimum $\left(x_{1}{ }^{*}\right.$, $\left.x_{2}{ }^{*}\right)$. Note that, compared to (A3), this condition has no rent-seeking term. It follows that in a symmetric equilibrium, $\hat{x}_{j}>x_{j}^{*}, j=1,2 .^{19}$

Proof of Proposition 2: The condition defining $\tilde{x}_{1}$ is

$$
\int_{0}^{1} \theta d F(\theta) v(L)=c^{\prime}\left(x_{1}\right)
$$

Comparing (A5) to (A4) immediately shows that $\tilde{x}_{1}>x_{1}^{*}$.

Proof of Proposition 3: Note first that the comparative statics from (11) are

$$
\begin{aligned}
& \frac{\partial s^{*}}{\partial \theta}=\frac{x_{1} v_{\lambda}(s L)+x_{2} v_{\lambda}((1-s) L)}{-S O C}>0 \\
& \frac{\partial s^{*}}{\partial x_{1}}=\frac{\theta v_{\lambda}(s L)}{-S O C}>0 \\
& \frac{\partial s^{*}}{\partial x_{2}}=\frac{(1-\theta) v_{\lambda}((1-s) L)}{S O C}<0,
\end{aligned}
$$

where $S O C$ is the second-order condition, which is negative. Now consider the choice of $x_{1}$ by heir one given $s^{*}$. (A similar analysis applies to heir two.) His problem is to

$$
\max \int_{0}^{1} \theta x_{1} v\left(s *\left(x_{1}, x_{2}, \theta\right) L\right) d F(\theta)-c\left(x_{1}\right)
$$

The condition defining his reaction function is

$$
\int_{0}^{1} \theta v\left(s^{*} L\right) d F(\theta)+\int_{0}^{1} \theta x_{1} v_{\lambda}\left(s^{*} L\right)\left(\frac{\partial s^{*}}{\partial x_{1}}\right) d F(\theta)=c^{\prime}\left(x_{1}\right) .
$$

\footnotetext{
${ }^{19}$ This is true regardless of whether the reaction functions are positively or negatively sloped.
} 
The second term on the left-hand side is the rent-seeking term and is positive by (A7). This term drops out when $x_{l}$ is chosen to maximize the expected joint return of the heirs. Thus, as under the best-qualified rule, the heirs over-invest in $x$.

Proof of Proposition 4: Consider first the land transactions following the allocation of land to the heirs. The return to heir one after buying an amount of land $\lambda_{1}$ is given by

$$
\theta x_{1} v\left(s L+\lambda_{1}\right)-c\left(x_{1}\right)-p \lambda_{1}
$$

Note that if heir one received some land from the testator (i.e., if $s>0$ ), then he can also sell land, in which case $\lambda_{1}$ would be negative in this expression. Heir two's return after buying (selling) $\lambda_{2}$ units of land is similarly given by

$$
(1-\theta) x_{2} v\left((1-s) L+\lambda_{2}\right)-c\left(x_{2}\right)-p \lambda_{2} .
$$

If both heirs transact optimally, then $\lambda_{1}^{*}$ and $\lambda_{2}^{*}$, respectively, satisfy the following firstorder conditions $\mathrm{s}^{20}$

$$
\begin{aligned}
& \theta x_{1} v_{\lambda}\left(s L+\lambda_{1}\right)-p=0 \\
& (1-\theta) x_{2} v_{\lambda}\left((1-s) L+\lambda_{2}\right)-p=0 .
\end{aligned}
$$

Together, these conditions imply that the marginal valuations of land by the heirs are equal, or

$$
\theta x_{1} v_{\lambda}\left(s L+\lambda_{1}\right)=(1-\theta) x_{2} v_{\lambda}\left((1-s) L+\lambda_{2}\right) .
$$

Now move back to stage two when the testator chooses $s$, assuming that he is unrestricted in his choice. He therefore chooses $s$ to maximize

$$
W=\theta x_{1} v\left(s L+\lambda_{1}^{*}\right)+(1-\theta) x_{2} v\left((1-s) L+\lambda_{2}^{*}\right)-c\left(x_{1}\right)-c\left(x_{2}\right)-p \lambda_{1}^{*}-p \lambda_{2}^{*} .
$$

The first derivative is 


$$
\begin{aligned}
& \frac{\partial W}{\partial s}=L\left[\theta x_{1} v_{\lambda}\left(s L+\lambda_{1}^{*}\right)-(1-\theta) x_{2} v_{\lambda}\left((1-s) L+\lambda_{2}^{*}\right)\right] \\
& +\left[\theta x_{1} v_{\lambda}\left(s L+\lambda_{1}^{*}\right)-p\right]\left(\frac{\partial \lambda_{1}^{*}}{\partial s}\right)+\left[(1-\theta) x_{2} v_{\lambda}\left((1-s) L+\lambda_{2}^{*}\right)-p\right]\left(\frac{\partial \lambda_{2}^{*}}{\partial s}\right) .
\end{aligned}
$$

Note that both expressions on the second line drop out by (A13) and (A14), while the first line drops out by (A15). Thus, (A17) equals zero for all values of s. This proves the irrelevance of $s$.

Proof of Proposition 5: Proposition 5 proves that the testator's choice of $s$ can be ignored. Thus, heir one's problem is to maximize his expected return, given by

$$
\int_{0}^{1}\left[\theta x_{1} v\left(s L+\lambda_{1}^{*}\right)-c\left(x_{1}\right)-p \lambda_{1}^{*}\right] d F(\theta)
$$

where $\lambda_{1}^{*}$ is a function of both $\theta$ and $x_{1}$ according to (A13). (Heir two's problem is symmetric.) The first-order condition for $x_{1}$ implies

$$
\int_{0}^{1}\left[\theta v\left(s L+\lambda_{1}^{*}\right)-c^{\prime}\left(x_{1}\right)+\left(\theta x_{1} v_{\lambda}-p\right)\left(\frac{\partial \lambda_{1}^{*}}{\partial x_{1}}\right)\right] d F(\theta)=0 .
$$

Since $\lambda_{1}^{*}$ is chosen optimally for all realizations of $\theta$, the term $\theta x_{1} v_{\lambda}-p=0$ by (A13).

Thus, (A19) reduces to

$$
E(\theta) v\left(s L+\lambda_{1}^{*}\right)-c^{\prime}\left(x_{1}\right)=0 .
$$

There are no rent-seeking effects here given the "irrelevance" of $s$. Further, heir one's choices of $x_{l}$ and $\lambda_{1}$ are socially optimal since there are no externalities.

\footnotetext{
${ }^{20}$ Note that the second-order conditions for an optimum imply that $v_{\lambda \lambda}<0$ at the $\lambda_{j}^{*}$ 's. Thus, the heirs will always end up in the range of decreasing returns to scale.
} 


\section{References}

Alston, L., Libecap, G., and Schneider, R., 1996. The Determinants and Impact of Property Rights: Land Titles on the Brazilian Frontier. Journal of Law, Economics, and Organization 12, 25-61.

Anderson, C. and Swimmer, E., 1997. Some Empirical Evidence on Property Rights of First Peoples. Journal of Economic Behavior and Organization 33, 1-22.

Becker, G., 1981. A Treatise on the Family. Harvard University Press, Cambridge, MA.

Bernheim, B., A. Shleifer, and Summers, L., 1985. The Strategic Bequest Motive. Journal of Political Economy 93, 1045-1077.

Besley, T., 1995. Property Rights and Investment Incentives: Theory and Evidence from Ghana. Journal of Political Economy 103, 903-937.

Buchanan, J., 1983. Rent Seeking, Noncompensated Transfers, and Laws of Succession. Journal of Law and Economics 26, 71-85.

Chu, C., 1991. Primogeniture. Journal of Political Economy 99, 78-99.

Coase, R., 1960. The Problem of Social Cost. Journal of Law and Economics 3, 1-44.

Colwell, P. and Munneke, H., 1999. Land Prices and Land Assembly in the CBD. Journal of Real Estate Finance and Economics 18, 163-180.

De Soto, H., 2000. The Mystery of Capital: Why Capitalism Triumphs in the West and Fails Everywhere Else. Basic Books, New York.

Friedman, L., 1985. A History of American Law, 2d. Edition. Touchstone, New York.

Gagan, D., 1976. The Indivisibility of Land: A Microeconomic Analysis of the System of Inheritance in Nineteenth-Century Ontario. Journal of Economic History 36, 126-141.

Goody, J., Thirsk, J., and Thompson, E., 1976. Family and Inheritance: Rural Society in Western Europe, 1200-1800. Cambridge University Press, Cambridge.

Habakkuk, J., 1994. Marriage, Debt, and the Estates System: English Landownership 1650-1950. Clarendon Press, Oxford.

Kennedy, L., 1991. Farm Succession in Modern Ireland: Elements of a Theory of Inheritance. Economic History Review 3, 477-499.

Menchik, P., 1980. Primogeniture, Equal Sharing, and the U. S. Distribution of Wealth. Quarterly Journal of Economics 94, 299-316. 
Miller, W., 1980. Primogeniture, Entails, and Endowments in English Classical Economics. History of Political Economy 12, 558-581.

Mortensen, D., 1982. Property Rights and Efficiency in Mating, Racing, and Related Games. American Economic Review 72, 968-979.

Murdock, G., 1967. Ethnographic Atlas. University of Pittsburgh Press, Pittsburgh.

Murdock, G. and Provost, K., 1973. Measurement of Cultural Complexity. Ethnology 4, 379-392.

Murdock, G. and White, D., 1969. Standard Cross Cultural Sample. Ethology 8, 329369.

Nagelkerke, N., 1991. A Note on the General Definition of the Coefficient of Determination. Biometrika 78, 691-2.

Polanyi, K., 1957. The Great Transformation. Beacon Press, Boston.

Posner, R., 1998. Economic Analysis of Law, $5^{\text {th }}$ Edition. Aspen Law \& Business, New York.

Pryor, F., 1973. Simulation of the Impact of Social and Economic Institutions on the Size Distribution of Income and Wealth. American Economic Review 63, 50-72.

Pryor, F., 1977. The Origins of the Economy. Academic Press, New York.

Smetters, K., 1999. Ricardian Equivalence: Long-Run Leviathan. Journal of Public Economics 73, 395-421.

Stark, R., 1987. Standard Cross Cultural Sample: Instructor's Book of Demonstrations. Showcase Presentational Software (DOS). Cognitive Development, Seattle.

Stiglitz, J., 1969. Distribution of Income and Wealth among Individuals. Econometrica 37, 382-397.

Stodder, J., 1995. The Evolution of Complexity in Primitive Exchange: Empirical Tests. Journal of Comparative Economics 20, 190-210

White, D., 1992. Ethnographic Atlas, MS-DOS Version 2.0. William C. Brown Publishers, Dubuque, Iowa. 
Table 1: Description of scale variables contained in analysis, descriptions contained in Murdock (1973) and SCCS

\begin{tabular}{|c|c|c|c|c|c|}
\hline $\begin{array}{l}\text { Scale } \\
\text { Variable }\end{array}$ & $=1$ if: & $=2$ if: & $=3$ if: & $=4$ if: & $=5$ if: \\
\hline $\begin{array}{l}\text { Writing and } \\
\text { Records }\end{array}$ & $\begin{array}{l}\text { No writing or } \\
\text { records }\end{array}$ & Mnemonic devices & $\begin{array}{l}\text { Non-written } \\
\text { records }\end{array}$ & $\begin{array}{l}\text { True writing; no } \\
\text { records }\end{array}$ & $\begin{array}{l}\text { True writing; } \\
\text { records }\end{array}$ \\
\hline $\begin{array}{l}\text { Fixity of } \\
\text { Residence }\end{array}$ & Nomadic & Seminomadic & Semisedentary & $\begin{array}{l}\text { Sedentary; } \\
\text { impermanent }\end{array}$ & Sedentary \\
\hline Agriculture & None & $10 \%$ food supply & $10 \%$; secondary & $\begin{array}{l}\text { Primary, not } \\
\text { intensive }\end{array}$ & $\begin{array}{l}\text { Primary, } \\
\text { intensive }\end{array}$ \\
\hline Urbanization & $\begin{array}{l}\text { Fewer than } 100 \\
\text { persons }\end{array}$ & 100-199 persons & 200-399 persons & 400-999 persons & 1000 persons \\
\hline $\begin{array}{l}\text { Technological } \\
\text { Specialization }\end{array}$ & $\begin{array}{l}\text { No pottery, } \\
\text { looms, or } \\
\text { metalworking }\end{array}$ & Pottery only & $\begin{array}{l}\text { Loom weaving } \\
\text { but not } \\
\text { metalworking }\end{array}$ & $\begin{array}{l}\text { Metalworking, } \\
\text { weavers, or } \\
\text { potters }\end{array}$ & $\begin{array}{c}\text { Smiths, } \\
\text { weavers, } \\
\text { potters }\end{array}$ \\
\hline $\begin{array}{l}\text { Land } \\
\text { transport }\end{array}$ & Human only & Pack animals & Draft animals & $\begin{array}{l}\text { Animal-drawn } \\
\text { vehicles }\end{array}$ & $\begin{array}{l}\text { Automotive } \\
\text { vehicles }\end{array}$ \\
\hline Money & None & $\begin{array}{c}\text { Domestically } \\
\text { Usable Currencies }\end{array}$ & Alien Currency & $\begin{array}{l}\text { Elementary } \\
\text { Forms }\end{array}$ & True Money \\
\hline $\begin{array}{l}\text { Population } \\
\text { Density }\end{array}$ & $\begin{array}{c}\text { less than } 1 \\
\text { person per } \\
\text { square mile }\end{array}$ & $\begin{array}{l}1-5 \text { persons per } \\
\text { square mile }\end{array}$ & $\begin{array}{l}5.1-25 \text { persons } \\
\text { per square mile }\end{array}$ & $\begin{array}{l}\text { 26-100 persons } \\
\text { per square mile }\end{array}$ & $\begin{array}{c}>100 \text { persons } \\
\text { per square } \\
\text { mile }\end{array}$ \\
\hline $\begin{array}{l}\text { Political } \\
\text { Integration }\end{array}$ & None & $\begin{array}{l}\text { Autonomous Local } \\
\text { Communities }\end{array}$ & $\begin{array}{l}1 \text { level above } \\
\text { community }\end{array}$ & $\begin{array}{l}2 \text { levels above } \\
\text { community }\end{array}$ & $\begin{array}{c}3 \text { levels } \\
\text { above } \\
\text { community }\end{array}$ \\
\hline $\begin{array}{l}\text { Social } \\
\text { Stratification }\end{array}$ & Egalitarian & Hereditary slavery & $\begin{array}{c}2 \text { social classes } \\
\text { no castes or } \\
\text { slavery }\end{array}$ & $\begin{array}{c}2 \text { social classes } \\
\text { castes and } \\
\text { slavery }\end{array}$ & $\begin{array}{l}>2 \text { social } \\
\text { classes, } \\
\text { castes, with } \\
\text { or without } \\
\text { slavery }\end{array}$ \\
\hline
\end{tabular}


Table 2: Correlations between Murdock's scale measures of development

\begin{tabular}{|c|c|c|c|c|c|c|c|c|c|c|c|}
\hline & $\begin{array}{l}\text { Writin } \\
\text { g and } \\
\text { Recs. }\end{array}$ & $\begin{array}{l}\text { Fix. of } \\
\text { Res. }\end{array}$ & Agric. & Urban. & $\begin{array}{l}\text { Tech. } \\
\text { Spec. }\end{array}$ & $\begin{array}{l}\text { Land } \\
\text { Trans. }\end{array}$ & Money & $\begin{array}{l}\text { Pop. } \\
\text { Dens. }\end{array}$ & Pol. Int. & $\begin{array}{l}\text { Soc. } \\
\text { Strat. }\end{array}$ & $\begin{array}{l}\text { Comp. } \\
\text { Comp. } \\
\text { Index }\end{array}$ \\
\hline $\begin{array}{l}\text { Writing and } \\
\text { Records }\end{array}$ & & $.247^{*}$ & $.343^{*}$ & $.422^{*}$ & $.490^{*}$ & $.627^{*}$ & $.530^{*}$ & $.362^{*}$ & $.578^{*}$ & $.621^{*}$ & $.711^{*}$ \\
\hline $\begin{array}{l}\text { Fixity of } \\
\text { Residence }\end{array}$ & $.247^{*}$ & & $.782^{*}$ & $.450^{*}$ & $.406^{*}$ & .076 & $.412^{*}$ & $.707^{*}$ & $.411^{*}$ & $.437^{*}$ & $.701^{*}$ \\
\hline Agriculture & $.343^{*}$ & $.782^{*}$ & & $.509^{*}$ & $.548^{*}$ & $.233^{*}$ & $.356^{*}$ & $.638^{*}$ & $.509^{*}$ & $.433^{*}$ & $.752^{*}$ \\
\hline Deg. Of Urban. & $.422^{*}$ & $.450^{*}$ & $.509^{*}$ & & $.435^{*}$ & $.397^{*}$ & $.375^{*}$ & $.560^{*}$ & $.476^{*}$ & $.489^{*}$ & $.705^{*}$ \\
\hline $\begin{array}{c}\text { Tech. } \\
\text { Specialization }\end{array}$ & $.490^{*}$ & $.406^{*}$ & $.548^{*}$ & $.435^{*}$ & & $.469^{*}$ & $.417^{*}$ & $.468^{*}$ & $.564^{*}$ & $.579^{*}$ & $.739^{*}$ \\
\hline Land Transport & $.627^{*}$ & .076 & $.233^{*}$ & $.397^{*}$ & $.469^{*}$ & & $.409^{*}$ & $.211^{*}$ & $.423^{*}$ & $.475^{*}$ & $.574^{*}$ \\
\hline Money & $.530^{*}$ & $.412^{*}$ & $.356^{*}$ & $.375^{*}$ & $.417^{*}$ & $.409^{*}$ & & $.557^{*}$ & $.531^{*}$ & $.470^{*}$ & $.700^{*}$ \\
\hline Pop. Density & $.362^{*}$ & $.707^{*}$ & $.638^{*}$ & $.560^{*}$ & $.468^{*}$ & $.211^{*}$ & & & $.565^{*}$ & $.500^{*}$ & $.783^{*}$ \\
\hline $\begin{array}{c}\text { Political } \\
\text { Integration }\end{array}$ & $.578^{*}$ & $.411^{*}$ & $.509^{*}$ & $.476^{*}$ & $.564^{*}$ & $.423^{*}$ & $.531^{*}$ & $.565^{*}$ & & $.710^{*}$ & $.786^{*}$ \\
\hline $\begin{array}{c}\text { Social } \\
\text { Stratification }\end{array}$ & $.621^{*}$ & $.437^{*}$ & $.433^{*}$ & $.489^{*}$ & $.579^{*}$ & $.475^{*}$ & $.470^{*}$ & $.500^{*}$ & $.710^{*}$ & & $.784^{*}$ \\
\hline $\begin{array}{l}\text { Land Market? } \\
(N=42)^{=}\end{array}$ & $.488^{*}$ & $.270^{* *}$ & $.554^{*}$ & $.473^{*}$ & $.531^{*}$ & $.329^{* *}$ & $.482^{*}$ & $.336^{* *}$ & $.397^{*}$ & $.450^{*}$ & $.628^{*}$ \\
\hline
\end{tabular}

* Denotes significance at the $1 \%$ level.

** Denotes signifcance at the $5 \%$ level.

= Spearman correlation coefficients, significance levels are results of Chi-square tests. 
Table 3: Means of technological scale variables and nature of land inheritance by region

\begin{tabular}{|c|c|c|c|c|c|c|c|}
\hline & $S C C S$ & $\begin{array}{l}\text { Sub- } \\
\text { Saharan } \\
\text { Africa }\end{array}$ & $\begin{array}{l}\text { Circum- } \\
\text { Mediter- } \\
\text { ranean }\end{array}$ & Eurasia & $\begin{array}{l}\text { Insular } \\
\text { Pacific }\end{array}$ & $\begin{array}{l}\text { North } \\
\text { America }\end{array}$ & $\begin{array}{l}\text { South } \\
\text { America }\end{array}$ \\
\hline$N$ & 186 & 28 & 28 & 34 & 31 & 33 & 32 \\
\hline $\begin{array}{l}\text { Writing and } \\
\text { Records }\end{array}$ & $\begin{array}{c}2.35 \\
(1.47)\end{array}$ & $1.32^{*}$ & $4.04^{*}$ & $3.00^{* *}$ & $1.87^{* *}$ & 2.18 & $1.72^{*}$ \\
\hline Fixity of Residence & $\begin{array}{c}3.76 \\
(1.56)\end{array}$ & 4.07 & 4.00 & 3.71 & $4.55^{* *}$ & $2.94^{*}$ & 3.44 \\
\hline Agriculture & $\begin{array}{c}3.45 \\
(1.51)\end{array}$ & 3.75 & $4.18^{*}$ & 3.62 & 3.74 & $2.30^{*}$ & 3.28 \\
\hline Urbanization & $\begin{array}{c}2.59 \\
(1.40)\end{array}$ & 2.61 & $3.32^{*}$ & 2.65 & 2.45 & 2.45 & 2.13 \\
\hline $\begin{array}{l}\text { Technological } \\
\text { Specialization }\end{array}$ & $\begin{array}{c}3.09 \\
(1.41)\end{array}$ & $3.75^{*}$ & $4.32^{*}$ & $3.68^{*}$ & $2.13^{*}$ & $2.06^{*}$ & 2.81 \\
\hline Land Transport & $\begin{array}{c}1.79 \\
(1.18)\end{array}$ & $1.14^{*}$ & $2.64^{*}$ & $2.50^{*}$ & $1.29^{*}$ & 1.79 & $1.34^{*}$ \\
\hline Money & $\begin{array}{c}2.51 \\
(1.48)\end{array}$ & 2.46 & $3.39^{*}$ & 2.67 & 2.97 & 2.15 & $1.45^{*}$ \\
\hline $\begin{array}{l}\text { Population } \\
\text { Density }\end{array}$ & $\begin{array}{c}2.86 \\
(1.56)\end{array}$ & 3.25 & $3.57^{*}$ & 3.18 & $3.55^{*}$ & $1.88^{*}$ & $1.91^{*}$ \\
\hline $\begin{array}{l}\text { Political } \\
\text { Integration }\end{array}$ & $\begin{array}{c}2.96 \\
(1.18)\end{array}$ & 3.07 & $3.89^{*}$ & 2.73 & 3.35 & $2.38^{*}$ & $2.39^{*}$ \\
\hline $\begin{array}{l}\text { Social } \\
\text { Stratification }\end{array}$ & $\begin{array}{c}2.45 \\
(1.46)\end{array}$ & 2.50 & $3.79^{*}$ & 2.94 & 2.23 & $1.82^{*}$ & $1.59^{*}$ \\
\hline $\begin{array}{l}\text { Composite } \\
\text { Complexity } \\
\text { Index }\end{array}$ & $\begin{array}{l}27.81 \\
(10.3)\end{array}$ & 27.92 & $37.14^{*}$ & $31.59^{* *}$ & 27.29 & $22.00^{*}$ & $22.03^{*}$ \\
\hline $\begin{array}{l}\text { Pred. Prob. of } \\
\text { Land Market }\end{array}$ & .1842 & $.1053^{* *}$ & $.4820^{*}$ & $.3155^{* *}$ & .1017 & $.0052^{*}$ & $.0069^{*}$ \\
\hline $\begin{array}{l}\text { Land } \\
\text { Inheritance: }\end{array}$ & & & & & & & \\
\hline$\%$ Fixed Rule & .64 & .75 & $.86^{*}$ & .77 & .61 & .55 & $.34^{*}$ \\
\hline $\begin{array}{l}\% \text { Fixed sole } \\
\text { heir }=\end{array}$ & .28 & $.62^{*}$ & .21 & .23 & .22 & .22 & $.00^{* *}$ \\
\hline
\end{tabular}

* Significant difference from rest-of-sample mean at the $1 \%$ level

${ }^{* *}$ Significant difference from rest-of-sample mean at the $5 \%$ level

= Spearman correlation coefficients, significance results are from Chi-square tests. 
Table 4a: Means by nature of land inheritance

\begin{tabular}{|c|c|c|c|c|c|c|c|c|c|c|c|c|c|}
\hline & $N$ & Writ. & $\begin{array}{l}\text { Fix.of } \\
\text { Res. }\end{array}$ & Agric. & Urban. & $\begin{array}{l}\text { Tech. } \\
\text { Spec. }\end{array}$ & $\begin{array}{l}\text { Land } \\
\text { Trans }\end{array}$ & Money & $\begin{array}{l}\text { Pop. } \\
\text { Dens }\end{array}$ & $\begin{array}{l}\text { Pol. } \\
\text { Int. }\end{array}$ & $\begin{array}{l}\text { Soc. } \\
\text { Strat }\end{array}$ & $\begin{array}{l}\text { Comp } \\
\text { Comp } \\
\text { Ind. }\end{array}$ & $\begin{array}{l}\text { Land } \\
\text { Market } \\
\text { Prob. }\end{array}$ \\
\hline $\begin{array}{l}\text { Rule } \\
\text { present }\end{array}$ & 119 & $2.61^{*}$ & $4.04^{*}$ & $3.65^{* *}$ & 2.70 & $3.50^{*}$ & $1.92^{* *}$ & $2.75^{*}$ & $\begin{array}{l}3.20 \\
*\end{array}$ & $3.14^{*}$ & $2.73^{*}$ & $30.2^{*}$ & $.2408^{*}$ \\
\hline $\begin{array}{l}\text { Absence } \\
\text { of rule }\end{array}$ & 67 & 1.90 & 3.27 & 3.10 & 2.39 & 2.37 & 1.55 & 2.09 & 2.25 & 2.63 & 1.96 & 23.5 & .1290 \\
\hline $\begin{array}{l}\text { Rules } \\
\text { present: }\end{array}$ & & & & & & & & & & & & & \\
\hline $\begin{array}{l}\text { Fixed sole } \\
\text { heir }\end{array}$ & 32 & 2.28 & 4.16 & 3.84 & 2.84 & 3.88 & 1.75 & 2.64 & 3.25 & 3.21 & 2.88 & 30.7 & .2107 \\
\hline $\begin{array}{l}\text { Equal } \\
\text { shares }\end{array}$ & 86 & 2.72 & 3.99 & 3.57 & 2.65 & 3.38 & 2.00 & 2.79 & 3.17 & 3.12 & 2.67 & 30.0 & .2354 \\
\hline
\end{tabular}


Table 5: Logistic models

\begin{tabular}{|c|c|c|c|c|}
\hline & Model 1 & Model 1a & Model II & Model IIa \\
\hline Dependent Variable & $\begin{array}{l}\text { Rule } \\
\text { present? }\end{array}$ & $\begin{array}{l}\text { Rule } \\
\text { present? }\end{array}$ & $\begin{array}{l}\text { Fixed Sole } \\
\text { Heir? }\end{array}$ & $\begin{array}{l}\text { Fixed Sole } \\
\text { Heir? }\end{array}$ \\
\hline Constant & $\begin{array}{l}-3.446^{*} \\
(1.025)\end{array}$ & $\begin{array}{l}-3.704^{*} \\
(.931)\end{array}$ & $\begin{array}{l}-1.907 \\
(1.523)\end{array}$ & $\begin{array}{l}-2.308^{*} \\
(.763)\end{array}$ \\
\hline Writing and Records & $\begin{array}{l}.508^{* *} \\
(.231)\end{array}$ & $\begin{array}{l}.538^{* *} \\
(.226)\end{array}$ & $\begin{array}{l}-.379 \\
(.255)\end{array}$ & $\begin{array}{l}-.305^{* *} \\
(.159)\end{array}$ \\
\hline Fixity of Residence & $\begin{array}{l}.337^{* * *} \\
(.219)\end{array}$ & $\begin{array}{l}.377^{* * *} \\
(.210)\end{array}$ & $\begin{array}{l}-.070 \\
(.302)\end{array}$ & \\
\hline Agriculture & $\begin{array}{l}-.428^{* * *} \\
(.225)\end{array}$ & $\begin{array}{l}-.490^{*} \\
(.213)\end{array}$ & $\begin{array}{l}.142 \\
(.298)\end{array}$ & \\
\hline Urbanization & $\begin{array}{l}-.177 \\
(.179)\end{array}$ & & $\begin{array}{l}.148 \\
(.243)\end{array}$ & \\
\hline $\begin{array}{l}\text { Technological } \\
\text { Specialization }\end{array}$ & $\begin{array}{l}.789^{*} \\
(.190)\end{array}$ & $\begin{array}{l}.807^{*} \\
(.187)\end{array}$ & $\begin{array}{l}.407^{* * *} \\
(.242)\end{array}$ & $\begin{array}{l}.482^{*} \\
(.212)\end{array}$ \\
\hline Land Transport & $\begin{array}{l}.307 \\
(.251)\end{array}$ & $\begin{array}{l}.290 \\
(.246)\end{array}$ & $\begin{array}{l}-.273 \\
(.283)\end{array}$ & \\
\hline Money & $\begin{array}{l}0.27 \\
(.175)\end{array}$ & & $\begin{array}{l}-.047 \\
(.214)\end{array}$ & \\
\hline Population Density & $\begin{array}{l}.493^{*} \\
(.203)\end{array}$ & $\begin{array}{l}.448^{*} \\
(.182)\end{array}$ & $\begin{array}{l}-.159 \\
(.263)\end{array}$ & \\
\hline Political Integration & $\begin{array}{l}-.100 \\
(.253)\end{array}$ & & $\begin{array}{l}.119 \\
(.282)\end{array}$ & \\
\hline Social Stratification & $\begin{array}{l}.122 \\
(.205)\end{array}$ & & $\begin{array}{l}.216 \\
(.224)\end{array}$ & \\
\hline Dual Stratification? & & & . & $\begin{array}{l}1.419^{*} \\
(.487)\end{array}$ \\
\hline Land Market Probability & $\begin{array}{l}-4.449^{* *} \\
(2.289)\end{array}$ & $\begin{array}{l}-4.674^{*} \\
(1.567)\end{array}$ & $\begin{array}{l}-.148 \\
(2.057)\end{array}$ & \\
\hline $\begin{array}{l}\mathrm{N} \\
\text { Psuedo-R }\end{array}$ & $\begin{array}{l}186 \\
.322 \\
\end{array}$ & $\begin{array}{l}186 \\
.315 \\
\end{array}$ & $\begin{array}{l}119 \\
.132 \\
\end{array}$ & $\begin{array}{l}119 \\
.184\end{array}$ \\
\hline
\end{tabular}




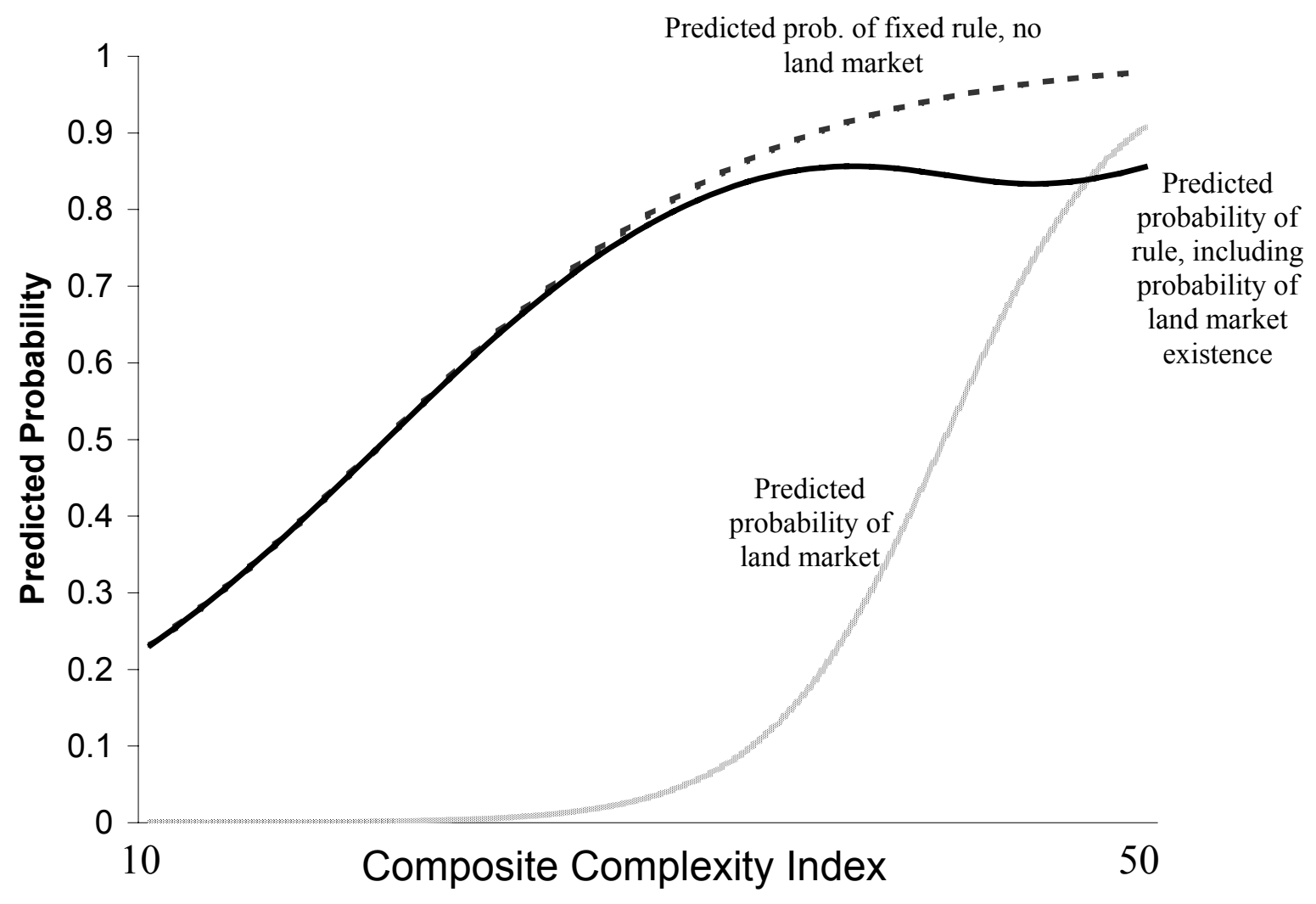

Figure 1: Predicted Probabilities of Land Markets and Fixed Inheritance Rules 